\title{
The excavation of two crop-marks at Huntingtower, Perthshire
}

\author{
G J Barclay*
}

\section{THE CROP-MARKS}

In the 1940s and 50s Mr Eric Bradley, a flying instructor at Scone, noticed and described a series of crop-marks to the W of Perth during attempts to trace the Roman road, from the Gask Ridge, at its last known point near Dupplin Lake some $8.5 \mathrm{~km}$ to the $\mathrm{SW}$ of the fort at Bertha. In 1969 Dr J X W P Corcoran admirably summarized the evidence available from Mr Bradley's notes and maps, Cambridge University Committee for Aerial Photography (CUCAP) photographs and RAF vertical photographs in an unpublished note, now in the NMRS. In 1967 a valuable series of aerial photographs of the Huntingtower sites was taken by John Dewar Studios for the Inspectorate of Ancient Monuments. Subsequently RCAHMS has photographed the area resulting in the discovery of further features. The location of the known crop-marks in the immediate vicinity of the castle, and the site of the second Huntingtower excavation is shown in fig 1.

The only known upstanding monument in the area is Huntingtower Barrow (1 on fig 1) a fine, tree-covered mound.

At the $\mathrm{W}$ end of the map are two crop-mark enclosures. The $\mathrm{S}$ of the two ( 2 on the figure) is a circular enclosure c $70 \mathrm{~m}$ in diameter, the presumed ditch broken at $\mathrm{SW}$ and NE. Immediately to the NE lies site 3, an oval enclosure also broken at the ends of its long axis at NE and SW. Along the axis is a rough line of 10 pits. At the $S$ gap in the ditch its terminals are slightly expanded, perhaps showing the position of terminal pits. To the SW of the $S$ ditch terminal a further pit may be associated with the entrance. The two enclosures share a common axis through their entrances and are almost certainly broadly contemporary. It is possible that they are 'ritual' monuments of the late $3 \mathrm{rd}$ or early 2 nd millennium $\mathrm{BC}$.

To the NE of 2 and 3 a double line of pits runs towards the narrow defile to the $W$ of Huntingtower Castle (site 4a). This pass is one of the few easy ways down the escarpment to the Almond valley, $\mathrm{N}$ of the castle. As the lines approach the castle the southern one changes in character; the large pits give way to a line of small pits. On the floor of the valley to the $\mathrm{N}$ of the escarpment a single line of pits is visible on one photograph (CUCAP ADV 20). This line (site 4b) may be the continuation of $4 a$. These features may be interpreted as the quarry pits of the Roman road.

To the W of the farm is the largest concentration of sites. Site 5, to the W of the steading is a large enclosure, appearing to be circular on most photographs. Concentric with it is a small ring of eight pits, $10 \mathrm{~m}$ in diameter. Other faint features are visible within it. Site 5 is crossed by a narrow dark line (site 6) forming an irregular enclosure between the edge of the escarpment and the steading.

To the $\mathrm{W}$ is a faintly defined, roughly circular enclosure (site 7) found only recently by RCAHMS. It is $30 \mathrm{~m}$ in diameter, defined by a narrow ditch. To the $S$ of site 5 is an irregular line of six clearly defined spots (? pits) site 8 . Immediately to its $S$ lies site 9 , visible as two parallel dark lines. Both lines are visible running parallel to the main road (A85) for some $260 \mathrm{~m}$. As the route of the road diverges to the $S$ the lines continue on their own to the $S$ of the farm, the castle and Huntingtower House, visible only intermittently. Near the E end of the feature

* Central Excavation Unit, Scottish Development Department (Ancient Monuments), 3-11 Melville Street, Edinburgh 


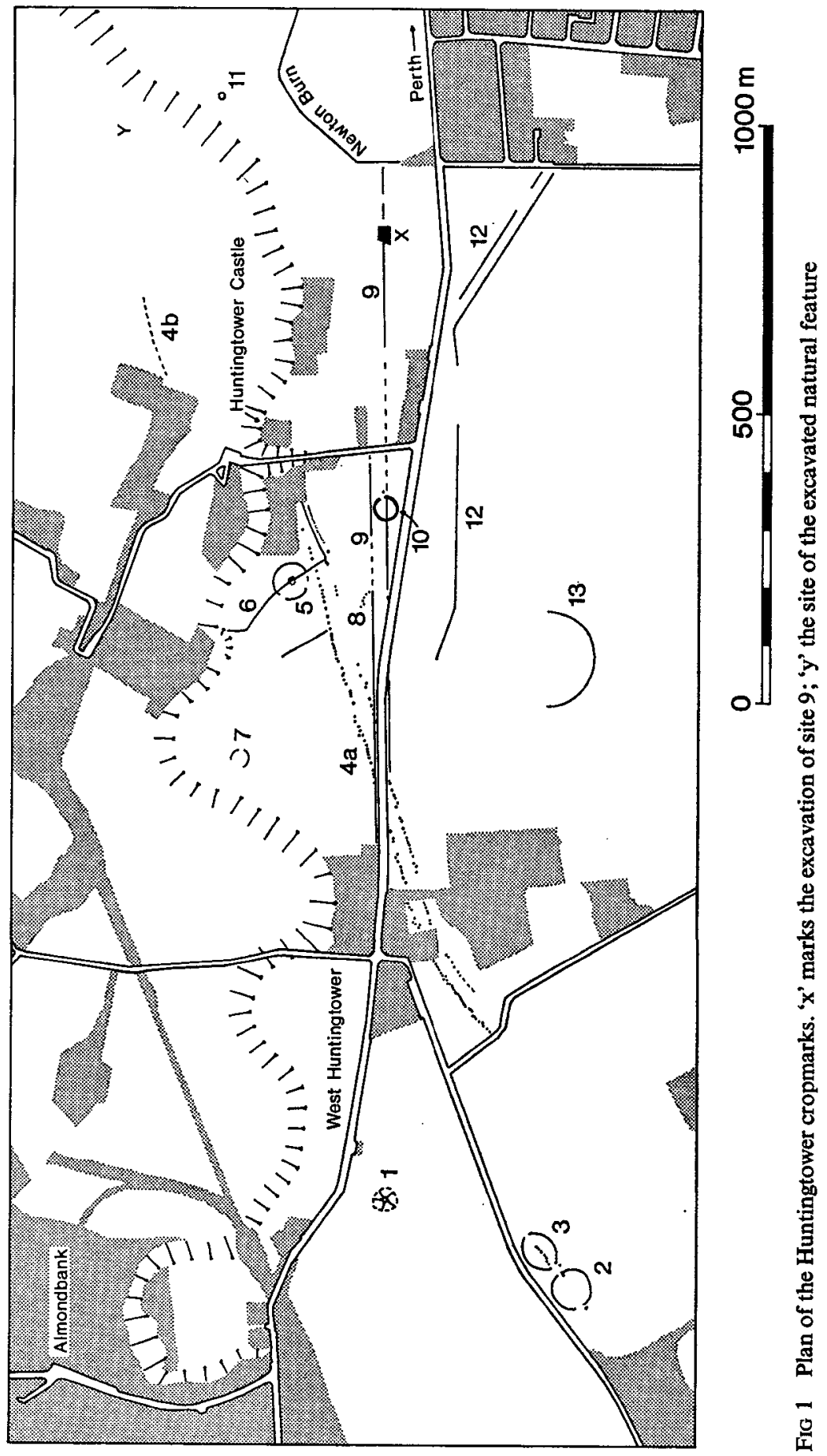


only the $\mathrm{S}$ line is visible as it crosses the valley, a tributary of the Newton Burn, now piped until its junction with the Burn, to the $E$. The total known length of the feature is $1160 \mathrm{~m}$. It was excavated in advance of road works and is described more fully below.

To the SW of Huntingtower Castle the $S$ line of site 9 crosses a circular enclosure $40 \mathrm{~m}$ in diameter broken at the ENE (site 10). This site has been interpreted as a possible class I henge or a related type of enclosure.

At the NE end of the map is a circular enclosure (site 11) c $10 \mathrm{~m}$ in diameter. Its perimeter seems unbroken.

To the $\mathrm{S}$ lies a further linear feature (site 12); two parallel lines, $20 \mathrm{~m}$ apart. This feature seems to change direction at the NW and one line continues to the W.

At the $S$ of the group half of a possibly circular enclosure is visible (site 13). The only photographs available suggest that the enclosure may be defined by pits.

\section{THE EXCAVATION}

The proposed line of the Perth Western Bypass, part of the A9 reconstruction, crosses the Huntingtower group of crop-marks from $\mathrm{N}$ to $\mathrm{S}$ at its $\mathrm{E}$ end. To the $\mathrm{N}$ of the $\mathrm{A} 85$ the route, cutting site 9 , was finalized in the mid 1970s. To the $S$ of the A85 the route has been the subject of litigation; site 12 may be threatened once the route is finalized.

In 1977 the author, for the Central Excavation Unit of SDD (Ancient Monuments), excavated part of the threatened section of site 9 and a poorly defined crop-mark to the $\mathrm{N}$, in the Almond Valley. The latter site proved to be natural, with the addition of modern pits (Discovery \& Excavation in Scotland 1977).

Prior to the excavation of site 9 it was believed that it was a cursus or processional way, aligned on site 1, the barrow, and associated with the supposed late 3rd/early 2 nd millennium sites represented by the crop-mark enclosures, though it has recently been identified as a Roman road (Hedges \& Buckley 1981).

The excavation area was laid out to allow the $S$ ditch of the supposed cursus to be investigated, together with a substantial area to the $\mathrm{N}$ and $\mathrm{S}$ of the feature. A second smaller area was laid out to locate the presumed $\mathrm{N}$ ditch which was not visible on aerial photographs at that point.

In brief, the excavation showed the following. The $S$ ditch was cut into colluvium within which quantities of medieval and post-medieval pottery were found, thus dating it and the ditch cut into it to recent imes. At the $\mathrm{N}$, in the second area, two ditches running $\mathrm{E}-\mathrm{W}$, rather than the expected single ditch, were found, likewise cut into recent colluvium. At the $\mathrm{E}$ end of the $\mathrm{S}$ area a compacted pebble surface was found under the colluvium. This appears to have been of natural origin as were irregular lines of stone found in the $\mathrm{W}$ part of area 1.

\section{DISCUSSION}

The supposed cursus at Huntingtower was proved by excavation to be modern. However its function is still not clear. The fact that it runs parallel to the road for some distance might suggest that it was in some way associated with it, perhaps marking the line of a route subsequently changed. Examination of the estate records failed to assist the interpretation.

Though the cursus has been discredited as a prehistoric monument the rest of the group is still of interest, though the idea of their forming a complex, as was tentatively suggested by Corcoran in his unpublished note, cannot be sustained without excavation. Sites 2 and 3 seem to be related but the mere proximity of the sites to each other cannot prove association. 
To the $\mathrm{W}$ of the area illustrated on the figure are two ring-ditches at Marlefield (NO 058245 ), an enclosure at Pow Bridge (NO 054 244) and, also at Pow Bridge, a number of possible pit alignments, all crop-mark sites. To the $\mathrm{N}$ of the River Almond a small hengiform enclosure with two opposed entrances at Berthapark may be drawn into the consideration of the possible late 3rd and early 2 nd millennium activity at Huntingtower.

Though the excavation of site 9 at Huntingtower was disappointing, the results should be welcomed as an object lesson in the limitations of the interpretation of aerial photographs without supporting excavation.

\section{ACKNOWLEDGMENTS}

I would like to thank Mr J S Rideout for preparing the map of the crop-marks, in the process finding new sections of sites 4 and 12, and for his comments on the manuscript. I would also thank the following for their work on the excavations: Ms J Kendrick, Mr J Morfey, Mr P N Tavener, Mr P Leslie, Mr D Lewis, Mr M Brooks, Dr D Morton and all the volunteers.

Mr J C C Romans was kind enough to visit the site and comment on the soils. My thanks also to the Ancient Monuments Laboratory, London for carrying out the geophysical survey of Huntingtower North.

Finally my thanks to Dr D J Breeze for his comments on the manuscript and his constant support.

\section{REFERENCE}

Hedges, J D \& Buckley, D G 1981 Springfield Cursus and the Cursus Problem. Chelmsford. (=Essex County Council Occas Pap, 1).

The Society is indebted to the Scottish Development Department (Ancient Monuments) for a grant towards the publication of this note 